(Supporting Information)

\title{
Synthesis and Chirality Sensing Properties of Poly[(phenyleneethynylene)-alt-
}

\section{(carboxybiphenyleneethynylene)]s}

Katsuhiro Maeda, ${ }^{*}$ Kohei Morioka, and Eiji Yashima*

Department of Molecular Design and Engineering, Graduate School of Engineering, Nagoya University, Chikusa-ku, Nagoya 464-8603, Japan.

\section{Experimental Section}

Instruments. Melting points were measured on a Yanako melting point apparatus and are uncorrected. NMR spectra were taken on a Varian Mercury $300\left(300 \mathrm{MHz}\right.$ for ${ }^{1} \mathrm{H}$ and $75 \mathrm{MHz}$ for ${ }^{13} \mathrm{C}$ ) or a Varian VXR-500S (500 MHz for ${ }^{1} \mathrm{H}$ and $125 \mathrm{MHz}$ for ${ }^{13} \mathrm{C}$ ) spectrometer in $\mathrm{CDCl}_{3}$ or DMSO- $d_{6}$ using tetramethylsilane (TMS) (for $\mathrm{CDCl}_{3}$ ) or a solvent residual peak (for DMSO- $d_{6}$ ) as the internal standard. Recycling preparative HPLC was performed with an LC-918 liquid chromatograph (JAI, Tokyo, Japan) equipped with a UV-visible detector (JAI UV 310). HPLC columns, JAIGEL-1H and JAIGEL-2H $\left(60 \times 2 \mathrm{~cm}\right.$ (i.d.)) were connected in series, and $\mathrm{CHCl}_{3}$ was used as the eluent. IR spectra were recorded using a Jasco Fourier Transform IR-620 spectrophotometer (Jasco, Hachioji, Japan). Absorption and CD spectra were measured in a 30mm quartz cell on a Jasco V-560 or V-570 spectrophotometer and a Jasco J-725 or J-820 spectropolarimeter, respectively. Fluorescence spectra were measured in a 10-mm quartz cell by use of a Jasco FP 6500 spectrofluorometer. SEC measurements were performed with a Jasco PU980 liquid chromatograph equipped with a UV (254 nm; Jasco UV-970) detector at $40{ }^{\circ} \mathrm{C}$. A Tosoh (Tokyo, Japan) TSKgel Multipore $\mathrm{H}_{\mathrm{XL}}-\mathrm{M}$ SEC column $\left(30 \mathrm{~cm}\right.$ ) was connected and $\mathrm{CHCl}_{3}$ was used as the eluent at a flow rate of $1.0 \mathrm{~mL} / \mathrm{min}$. The molecular weight calibration curve was 
obtained with polystyrene standards (Tosoh).

Materials. Anhydrous THF (water content $<0.005 \%$ ), toluene (water content $<0.005 \%$ ), and pyridine (water content $<0.005 \%$ ) were purchased from Wako (Osaka, Japan) and stored under nitrogen. Copper(I) iodide and iodine were obtained from Kishida (Osaka, Japan). Acetyl chloride, boron tribromide $\left(\mathrm{BBr}_{3}\right)$, and 1,3-dimethoxybenzene were purchased from Aldrich (Milwaukee, WI, USA). 1,2-Dimethoxybenzene (veratrole) and mercury(II) oxide (HgO) were purchased from Wako. Tetrakis(triphenylphosphine) palladium(0) and 1,4-dimethoxybenzene were obtained from Tokyo Kasei (TCI, Tokyo, Japan). (R)-(+)-1-(1-Naphthyl)ethylamine ((R)-9) and $(R)$-1-phenylethylamine $((R)-\mathbf{1 0})$ were kindly supplied from Yamakawa Chemical (Tokyo, Japan), distilled under reduced pressure, and stored under nitrogen. Optically active diamines were available from TCI. 2-[2-(2-Methoxyethoxy)ethoxy]ethyl $p$-toluenesulfonate was prepared from 2-[2-(2-methoxyethoxy)ethoxy]ethanol (Aldrich) and $p$-toluenesulfonyl chloride (Kishida) by the conventional method.

2,2'-Diacetoxy-3,3'-bis(methoxycarbonyl)-5,5'-diethynylbiphenyl (2). This compound was prepared from 3,3'-bis(methoxycarbonyl)-5,5'-diethynyl-2,2'-biphenol ${ }^{1}$ with acetyl chloride in 93\% yield. To a solution of 3,3'-bis(methoxycarbonyl)-5,5'-diethynyl-2,2'-biphenol (300 mg, $0.856 \mathrm{mmol})$ in THF $(55.0 \mathrm{~mL})$ and pyridine $(0.66 \mathrm{~mL} 8.56 \mathrm{mmol})$ was added dropwise acetyl chloride $(0.62 \mathrm{~mL}, 8.56 \mathrm{mmol})$ at room temperature. After stirring at room temperature for $48 \mathrm{~h}$, the reaction mixture was diluted with ethyl acetate $(50 \mathrm{~mL})$, and the solution was washed with aqueous $\mathrm{HCl}(1 \mathrm{~N})$ and water. After the organic layer was dried over $\mathrm{Na}_{2} \mathrm{SO}_{4}$, the solvent was removed by evaporation. The crude product was chromatographed on silica gel with $\mathrm{CHCl}_{3}$ as the eluent and then further purified by recycling preparative HPLC to give $\mathbf{2}$ as white solids (348 mg, 93.0 \%). $\quad \operatorname{Mp} 149.6-151.3{ }^{\circ} \mathrm{C} . \mathrm{IR}\left(\mathrm{KBr}, \mathrm{cm}^{-1}\right): 3301\left(v_{\equiv \mathrm{C}-\mathrm{H}}\right), 1759\left(v_{\mathrm{C}=\mathrm{O}}\right), 1716\left(v_{\mathrm{C}=\mathrm{O}}\right) .{ }^{1} \mathrm{H}$ NMR $\left(\mathrm{CDCl}_{3}, \mathrm{rt}, 300 \mathrm{MHz}\right): \delta 2.09\left(\mathrm{~s}, \mathrm{CH}_{3}, 6 \mathrm{H}\right), 3.13(\mathrm{~s}, \equiv \mathrm{C}-\mathrm{H}, 2 \mathrm{H}), 3.89\left(\mathrm{~s}, \mathrm{CH}_{3}, 6 \mathrm{H}\right), 7.57(\mathrm{~d}, J=$ 
$2.1 \mathrm{~Hz}$, aromatic, $2 \mathrm{H}), 8.17(\mathrm{~d}, J=2.1 \mathrm{~Hz}$, aromatic, $2 \mathrm{H}) .{ }^{13} \mathrm{C} \mathrm{NMR}\left(\mathrm{CDCl}_{3}, \mathrm{rt}, 75 \mathrm{MHz}\right): \delta 20.6$, $52.5\left(\mathrm{CH}_{3}\right), 78.9,81.2(\mathrm{C} \equiv \mathrm{C}-\mathrm{H}), 120.2,124.2,131.4,135.5,138.4,148.1$ (aromatic), 164.1 $(\mathrm{C}=\mathrm{O}), 168.9(\mathrm{C}=\mathrm{O})$. Anal. Calcd for $\mathrm{C}_{24} \mathrm{H}_{18} \mathrm{O}_{8}: \mathrm{C}, 66.36 ; \mathrm{H}, 4$.18. Found: $\mathrm{C}, 66.35 ; \mathrm{H}, 4.23$. MS (FAB+): Calcd for $\mathrm{C}_{24} \mathrm{H}_{19} \mathrm{O}_{8}(\mathrm{M}+\mathrm{H}), 435.11$; found, 435.11.

1,4-Diiodo-2,5-bis\{2-[2-(2-methoxyethoxy)ethoxy]ethoxy\}benzene (3a). This compound was prepared from 1,4-dimethoxybenzene according to the literature. ${ }^{2,3}$

Spectroscopic data of 3a. ${ }^{1} \mathrm{H}$ NMR $\left(\mathrm{CDCl}_{3}, \mathrm{rt}, 300 \mathrm{MHz}\right): \delta 3.38\left(\mathrm{~s}, \mathrm{CH}_{3}, 6 \mathrm{H}\right), 3.54-3.57(\mathrm{~m}$, $\left.\mathrm{CH}_{2}, 4 \mathrm{H}\right), 3.65-3.70\left(\mathrm{~m}, \mathrm{CH}_{2}, 8 \mathrm{H}\right), 3.77-3.81\left(\mathrm{~m}, \mathrm{CH}_{2}, 4 \mathrm{H}\right), 3.86-3.89\left(\mathrm{~m}, \mathrm{CH}_{2}, 4 \mathrm{H}\right), 4.09-4.12$ (m, $\left.\mathrm{CH}_{2}, 4 \mathrm{H}\right), 7.24$ (s, aromatic, $\left.2 \mathrm{H}\right) .{ }^{13} \mathrm{C} \mathrm{NMR}\left(\mathrm{CDCl}_{3}, \mathrm{rt}, 75 \mathrm{MHz}\right): \delta 59.0\left(\mathrm{CH}_{3}\right), 69.5,70.2$, 70.5, 70.7, 71.1, $71.9\left(\mathrm{CH}_{2}\right), 86.3,123.4,153.0$ (aromatic).

1,3-Bis $\{2-[2-(2-m e t h o x y e t h o x y)$ ethoxy]ethoxy\}benzene. $\quad$ To a solution of 1,3dimethoxybenzene $(1.50 \mathrm{~g}, 10.9 \mathrm{mmol})$ in $\mathrm{CH}_{2} \mathrm{Cl}_{2}(10 \mathrm{~mL})$ was added dropwise $26.2 \mathrm{~mL}$ of $\mathrm{BBr}_{3}$ in $\mathrm{CH}_{2} \mathrm{Cl}_{2}(1.0 \mathrm{M}, 26.2 \mathrm{mmol})$ under nitrogen at $-78{ }^{\circ} \mathrm{C}$. The reaction mixture was allowed to warm to room temperature and further stirred at room temperature for $24 \mathrm{~h}$. After ice water was added, the solution was extracted with ethyl acetate. The organic layer was washed with water and then dried over $\mathrm{Na}_{2} \mathrm{SO}_{4}$. After filtration, the filtrate was evaporated, yielding 1,3dihydroxybenzene as white solids (1.19 g, $99 \%$ ). ${ }^{1} \mathrm{H}$ NMR (DMSO- $d_{6}$, rt, $300 \mathrm{MHz}$ ): $\delta 6.16-6.19$ (m, aromatic, 3H), 6.88-6.94 (m, aromatic, $1 \mathrm{H}), 9.14(\mathrm{~s}, \mathrm{OH}, 2 \mathrm{H}) .{ }^{13} \mathrm{C}$ NMR (DMSO- $d_{6}, \mathrm{rt}, 75$ MHz): $\delta 102.5,106.2,129.7,158.5$ (aromatic).

To a solution of 1,3-dihydroxybenzene $(600 \mathrm{mg}, \quad 5.45 \mathrm{mmol})$ and 2-[2-(2methoxyethoxy)ethoxy]ethyl $p$-toluenesulfonate $(4.17 \mathrm{~g}, 13.1 \mathrm{mmol})$ in $\mathrm{EtOH}(4.60 \mathrm{~mL})$ was added potassium carbonate $(2.27 \mathrm{~g}, 16.4 \mathrm{mmol})$ and the mixture was stirred under reflux for $17 \mathrm{~h}$. After the reaction mixture was allowed to cool to room temperature, the solution was diluted with ethyl acetate, washed with aqueous $\mathrm{HCl}(1 \mathrm{~N})$ and water, and the organic layer was then dried 
over $\mathrm{Na}_{2} \mathrm{SO}_{4}$. The solvent was removed by evaporation, and the crude product was purified by silica gel chromatography with $\mathrm{CHCl}_{3}$ as the eluent to give 1,3-bis\{2-[2-(2methoxyethoxy)ethoxy]ethoxy\}benzene as a colorless oil $(1.52 \mathrm{~g}, 70.0 \%) .{ }^{1} \mathrm{H} \mathrm{NMR}\left(\mathrm{CDCl}_{3}, \mathrm{rt}\right.$, $300 \mathrm{MHz}): \delta 3.38\left(\mathrm{~s}, \mathrm{CH}_{3}, 6 \mathrm{H}\right), 3.54-3.57\left(\mathrm{~m}, \mathrm{CH}_{2}, 4 \mathrm{H}\right), 3.64-3.70\left(\mathrm{~m}, \mathrm{CH}_{2}, 8 \mathrm{H}\right), 3.72-3.76(\mathrm{~m}$, $\left.\mathrm{CH}_{2}, 4 \mathrm{H}\right), 3.83-3.86\left(\mathrm{~m}, \mathrm{CH}_{2}, 4 \mathrm{H}\right), 4.09-4.12\left(\mathrm{~m}, \mathrm{CH}_{2}, 4 \mathrm{H}\right), 6.50-6.53$ (m, aromatic, 3H), 7.11$7.18(\mathrm{~m}$, aromatic, $1 \mathrm{H}) .{ }^{13} \mathrm{C} \mathrm{NMR}\left(\mathrm{CDCl}_{3}, \mathrm{rt}, 75 \mathrm{MHz}\right): \delta 59.4\left(\mathrm{CH}_{3}\right), 67.8,70.1,70.9,71.0,71.2$, $72.3\left(\mathrm{CH}_{2}\right), 102.2,107.5,130.2,160.4$ (aromatic). Anal. Calcd for $\mathrm{C}_{20} \mathrm{H}_{34} \mathrm{O}_{8}: \mathrm{C}, 59.68 ; \mathrm{H}, 8.51$. Found: C, 59.23; H, 8.53.

1,5-Diiodo-2,4-bis $\{2-[2-(2-m e t h o x y e t h o x y) e t h o x y]$ ethoxy\}benzene (3b). Regioselective dibromination of 1,3-bis\{2-[2-(2-methoxyethoxy)ethoxy]ethoxy\}benzene was carried out according to a reported procedure ${ }^{4}$ with a slight modification. A suspension of 1,3-bis $\{2-[2-(2-$ methoxyethoxy)ethoxy]ethoxy\}benzene (600 mg, $1.49 \mathrm{mmol}), \mathrm{HgO}(974 \mathrm{mg}, 4.47 \mathrm{mmol})$, and iodine (1.13 g, $4.47 \mathrm{mmol})$ in $\mathrm{CH}_{2} \mathrm{Cl}_{2}(6.0 \mathrm{~mL})$ was stirred at room temperature for $4 \mathrm{~h}$. After filtration, the filtrate was washed with a saturated aqueous $\mathrm{Na}_{2} \mathrm{~S}_{2} \mathrm{O}_{3}$ and water, and the organic layer was dried over $\mathrm{Na}_{2} \mathrm{SO}_{4}$. After evaporating the solvent, the residue was chromatographed on silica gel with ethyl acetate as the eluent and further purified by recycling preparative HPLC to give 3b as a yellow oil (776 mg, $80 \%) .{ }^{1} \mathrm{H} \mathrm{NMR}\left(\mathrm{CDCl}_{3}, \mathrm{rt}, 300 \mathrm{MHz}\right): \delta 3.38\left(\mathrm{~s}, \mathrm{CH}_{3}, 6 \mathrm{H}\right)$, 3.53-3.56 (m, $\left.\mathrm{CH}_{2}, 4 \mathrm{H}\right), 3.64-3.70\left(\mathrm{~m}, \mathrm{CH}_{2}, 8 \mathrm{H}\right), 3.79-3.82\left(\mathrm{~m}, \mathrm{CH}_{2}, 4 \mathrm{H}\right), 3.90-3.93\left(\mathrm{~m}, \mathrm{CH}_{2}\right.$, 4H), 4.13-4.17 (m, $\left.\mathrm{CH}_{2}, 4 \mathrm{H}\right), 6.46$ (s, aromatic, $\left.1 \mathrm{H}\right), 8.03$ (s, aromatic, $\left.1 \mathrm{H}\right) .{ }^{13} \mathrm{C} \mathrm{NMR}\left(\mathrm{CDCl}_{3}, \mathrm{rt}\right.$, $75 \mathrm{MHz}): \delta 59.3\left(\mathrm{CH}_{3}\right), 69.7,69.8,70.8,71.0,71.4,72.2\left(\mathrm{CH}_{2}\right), 99.1,147.0,159.2$ (aromatic). Anal. Calcd for $\mathrm{C}_{20} \mathrm{H}_{32} \mathrm{O}_{8} \mathrm{I}_{2} \bullet \mathrm{H}_{2} \mathrm{O}: \mathrm{C}, 35.73 ; \mathrm{H}, 5.10$. Found: C, 35.95; H, 4.87.

1,2-Diiodo-4,5-bis $\{2-[2-(2-m e t h o x y e t h o x y)$ ethoxy] $]$ thoxy $\}$ benzene (3c). This compound was prepared from 1,2-dimethoxybenzene according to the literature. ${ }^{5}$

Spectroscopic data of 3c. ${ }^{1} \mathrm{H}$ NMR $\left(\mathrm{CDCl}_{3}, \mathrm{rt}, 300 \mathrm{MHz}\right): \delta 3.38\left(\mathrm{~s}, \mathrm{CH}_{3}, 6 \mathrm{H}\right), 3.53-3.56(\mathrm{~m}$, 
$\left.\mathrm{CH}_{2}, 4 \mathrm{H}\right), 3.64-3.68\left(\mathrm{~m}, \mathrm{CH}_{2}, 8 \mathrm{H}\right), 3.70-3.74\left(\mathrm{~m}, \mathrm{CH}_{2}, 4 \mathrm{H}\right), 3.82-3.85\left(\mathrm{~m}, \mathrm{CH}_{2}, 4 \mathrm{H}\right), 4.10-4.13$ (m, $\left.\mathrm{CH}_{2}, 4 \mathrm{H}\right), 7.33$ (s, aromatic, $\left.2 \mathrm{H}\right) .{ }^{13} \mathrm{C} \mathrm{NMR}\left(\mathrm{CDCl}_{3}, \mathrm{rt}, 75 \mathrm{MHz}\right): \delta 59.0\left(\mathrm{CH}_{3}\right), 69.1,69.5$, 70.5, 70.6, 70.8, $71.9\left(\mathrm{CH}_{2}\right), 96.7,124.8,149.5$ (aromatic).

Polymerization. Polymerization of $\mathbf{2}$ with $\mathbf{3 a}-\mathbf{3 c}$ were carried out according to the literature method with a modification. ${ }^{6}$ A typical polymerization procedure is described below.

Monomer 2 (60.0 mg, $0.138 \mathrm{mmol})$, monomer 3a $(87.7 \mathrm{mg}, 0.134 \mathrm{mmol}), \mathrm{Pd}\left(\mathrm{PPh}_{3}\right)_{4}(9.28$ $\mathrm{mg}, 0.00804 \mathrm{mmol})$, and $\mathrm{CuI}(7.70 \mathrm{mg}, 0.0402 \mathrm{mmol})$ were placed in a dry glass ampule equipped with a magnetic stirrer bar and a three-way stopcock, which was then evacuated and flushed with nitrogen. After this evacuation-flush procedure was repeated three times, dry toluene $(1.06 \mathrm{~mL})$ and dry diisopropylamine $(0.45 \mathrm{~mL})$ were added with a syringe. The mixture was then heated at $60{ }^{\circ} \mathrm{C}$. After $24 \mathrm{~h}$, the resulting polymer was precipitated into a large amount of methanol, collected by centrifugation, and then dried in vacuo at room temperature to give poly4a as a yellow solid (106 mg, $94.6 \%)$. The poly-4a $(82.4 \mathrm{mg})$ was converted to poly-5a by hydrolysis of the ester groups in THF $(10 \mathrm{~mL})$ and a saturated aqueous $\mathrm{NaOH}(20 \mathrm{~mL})$ at room temperature for $24 \mathrm{~h}$. After evaporating the organic solvent, the solution was acidified with aqueous $\mathrm{HCl}(1 \mathrm{~N})$. The precipitated polymer was then collected by centrifugation and dried in vacuo at room temperature for $12 \mathrm{~h}(65.6 \mathrm{mg}, 92 \%)$.

Spectroscopic data of poly-5a. IR $\left(\mathrm{KBr}, \mathrm{cm}^{-1}\right): 1671\left(v_{\mathrm{C}=\mathrm{O}}\right) .{ }^{1} \mathrm{H}$ NMR $\left(\mathrm{DMSO}-d_{6}, \mathrm{rt}, 300\right.$ $\mathrm{MHz}): \delta 3.15\left(\mathrm{~s}, \mathrm{CH}_{3}, 6 \mathrm{H}\right), 3.30-3.33\left(\mathrm{~m}, \mathrm{CH}_{2}, 4 \mathrm{H}\right), 3.38-3.46\left(\mathrm{~m}, \mathrm{CH}_{2}, 8 \mathrm{H}\right), 3.62-3.65\left(\mathrm{~m}, \mathrm{CH}_{2}\right.$, 4H), 3.77 (br, $\left.\mathrm{CH}_{2}, 4 \mathrm{H}\right), 4.16\left(\mathrm{br}, \mathrm{CH}_{2}, 4 \mathrm{H}\right), 7.21$ (s, aromatic, $\left.2 \mathrm{H}\right), 7.65(\mathrm{~d}, J=2.1 \mathrm{~Hz}$, aromatic, $2 \mathrm{H}), 7.98(\mathrm{~d}, J=2.1 \mathrm{~Hz}$, aromatic, $2 \mathrm{H})$. Anal. Calcd for $\mathrm{C}_{38} \mathrm{H}_{40} \mathrm{O}_{14}: \mathrm{C}, 63.33 ; \mathrm{H}, 5.59$. Found: C, 63.32; H, 5.72 .

Spectroscopic data of poly-5b. IR $\left(\mathrm{KBr}, \mathrm{cm}^{-1}\right): 1673\left(v_{\mathrm{C}=\mathrm{O}}\right) .{ }^{1} \mathrm{H}$ NMR $\left(\mathrm{DMSO}-d_{6}, \mathrm{rt}, 300\right.$ $\mathrm{MHz}): \delta$ 3.15-3.80 (br, $\left.\mathrm{CH}_{2}, 26 \mathrm{H}\right), 4.26$ (br, $\left.\mathrm{CH}_{2}, 4 \mathrm{H}\right), 6.79$ (br, aromatic, $\left.1 \mathrm{H}\right)$, 7.57-7.59 (br, aromatic, $3 \mathrm{H}), 7.93$ (s, aromatic, $2 \mathrm{H}$ ). Anal. Calcd for $\mathrm{C}_{38} \mathrm{H}_{40} \mathrm{O}_{14}: \mathrm{C}, 63.33 ; \mathrm{H}, 5.59$. Found: $\mathrm{C}$, 


\subsection{3; H, 5.64 .}

Spectroscopic data of poly-5c. IR $\left(\mathrm{KBr}, \mathrm{cm}^{-1}\right)$ : $1673\left(v_{\mathrm{C}=0}\right) .{ }^{1} \mathrm{H}$ NMR (DMSO- $d_{6}, \mathrm{rt}, 300$ MHz): $\delta 3.18$ (s, $\left.\mathrm{CH}_{3}, 6 \mathrm{H}\right), 3.38-3.72$ (br, $\left.\mathrm{CH}_{2}, 20 \mathrm{H}\right), 4.12$ (br, $\left.\mathrm{CH}_{2}, 4 \mathrm{H}\right), 7.16$ (br, aromatic, $2 \mathrm{H}$ ), 7.68 (br, aromatic, $2 \mathrm{H}$ ), 7.96 (s, aromatic, $2 \mathrm{H}$ ). Anal. Calcd for $\mathrm{C}_{38} \mathrm{H}_{40} \mathrm{O}_{14}: \mathrm{C}, 63.33 ; \mathrm{H}, 5.59$. Found: C, 63.34; H, 5.63.

CD Measurements. Anhydrous THF was used throughout for all the measurements. All the CD spectra were measured in THF in a $30-\mathrm{mm}$ quartz cell at room temperature. A typical experimental procedure is described below. A stock solution of poly-5a $(1.0 \mathrm{mg} / \mathrm{mL})([$ poly-5a] $=$ $1.39 \mathrm{mM}$ monomer units) in THF was prepared in a 2-mL flask equipped with a stopcock. A stock solution of $(1 R, 2 R)-6(5.25 \mathrm{mg} / \mathrm{mL})$ in THF was also prepared in a 2 -mL flask equipped with a stopcock. A $90 \mu \mathrm{L}$ aliquot of the stock solution of poly-5a was transferred to a $10-\mathrm{mL}$ flask equipped with a stopcock using a Hamilton microsyringe. To the flask was added $200 \mu \mathrm{L}$ of the stock solution of $(1 R, 2 R)-\mathbf{6}([(1 R, 2 R)-\mathbf{6}] /[$ poly-5a $]=40)$ and the solution was diluted with THF in order to keep the poly-5a concentration at $0.0124 \mathrm{mM}$, and the $\mathrm{CD}$ and absorption spectra were measured.

Molecular Modeling and Calculations. Molecular modeling and molecular mechanics calculation were performed using the Dreiding force field (version 2.21) as implemented in the CERIUS $^{2}$ software (version 3.8, Molecular Simulations, Burlington, MA) running on an Indigo ${ }^{2}-$ Impact graphics workstation (Silicon Graphics, Mountain View, CA). The polymer models of poly-5a-poly-5c (10 repeating monomer units) were constructed using a Polymer Builder module in CERIUS ${ }^{2}$. The two triethyleneglycol groups on the phenylene units were substituted with methoxy groups for clarity. Charges on the atoms of poly-5a-poly-5c were calculated using charge equilibration (QEq) in $\mathrm{CERIUS}^{2}$; the total charges of the molecules were zero. All of the biphenol units were fixed in the cisoid (S)-conformation and the twist angles about single 
bonds between the phenyl and ethynyl groups were allowed to rotate from 0 to $330^{\circ}$ at $30^{\circ}$ intervals. The constructed models $(10$ mer $)$ were optimized by the conjugate gradient method. The energy minimization was continued until the root-mean-square (rms) value became less than

$0.1 \mathrm{kcal} \mathrm{mol}^{-1} \AA^{-1}$. The obtained right-handed helical structures of poly-5a-poly-5c are shown in Figure S-1. However, the preferable helical conformations of poly-5a-poly-5c (right- or lefthanded helix) complexed with $(1 R, 2 R)$ - or $(1 S, 2 S)$-6 have not yet been determined, therefore, we assume that poly-5- $(1 R, 2 R)-6$ may have a right-handed helix when the biphenol units form the $(S)$-conformation on the basis of a plausible structure of the model cyclic tetramer complex of $\mathbf{1}$ with $(1 R, 2 R)-6 .{ }^{1}$ Apparently, more detailed molecular mechanics and molecular dynamics calculations of poly-5a-poly-5c together with the solid-state structure determinations of the $\mathbf{1}-(1 R, 2 R)-\mathbf{6}$ complex may be necessary to propose more reliable helical structural models.

\section{References}

(1) Morioka, K.; Tamagawa, N.; Maeda, K.; Yashima, E. Chem. Lett. 2006, 35, 110.

(2) Zhang, J.; Chui, Y.; Wang, M.; Liu, J. Chem. Comm. 2002, 2526.

(3) Swager, T. M.; Gil, C. J.; Wrighton, M. S. J. Phys. Chem. 1995, 99, 4886.

(4) Orito, K.; Hatakeyama, T.; Takeo, M.; Suginome, H. Synthesis 1995, 1273.

(5) Wang, J.; Lu, M.; Pan, Y.; Peng, Z. J. Org. Chem. 2002, 67, 7781.

(6) (a) Bunz, U. H. F.; Chem. Rev. 2000, 100, 1605; (b) Zhou, Q.; Swager, T. M. J. Am. Chem. Soc. 1995, 117, 12593.

(7) (a) Rappé, A. K.; Goddard III, W. A. J. Phys. Chem. 1991, 95, 3358 (b) Mayo, S. L.; Olafson, B. D.; Goddard III, W. A. J. Phys. Chem. 1990, 94, 8897. 

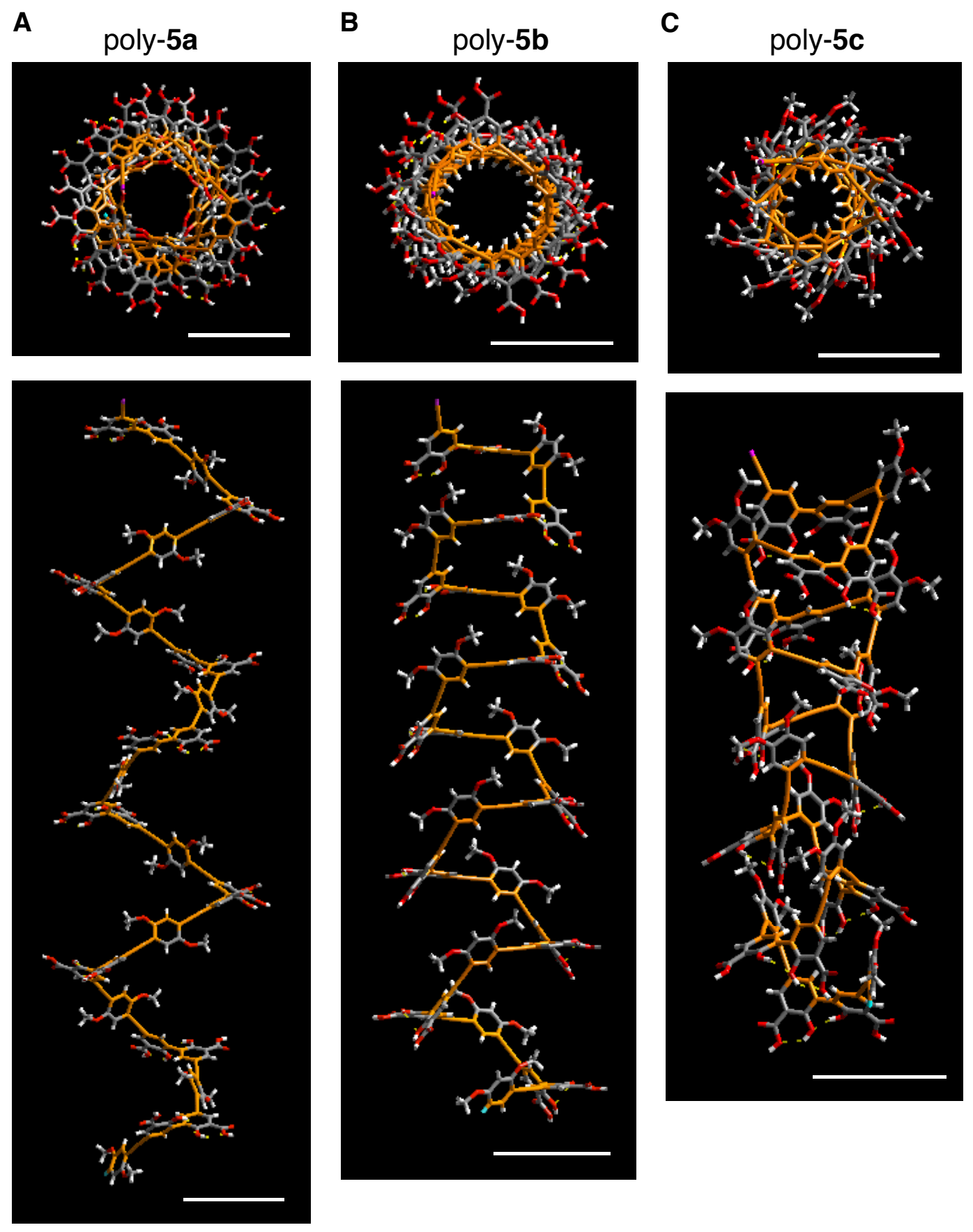

Figure S-1. Optimized possible helical conformations of poly-5a (A), poly-5b (B), and poly-5c (C). Shown are cylinder models in top (top) and side view (bottom): scale bar, $1.0 \mathrm{~nm}$. The two triethyleneglycol groups on the phenylene units were substituted with methoxy groups and some of the carbon atoms along the polymer backbones are represented by orange for clarity. 


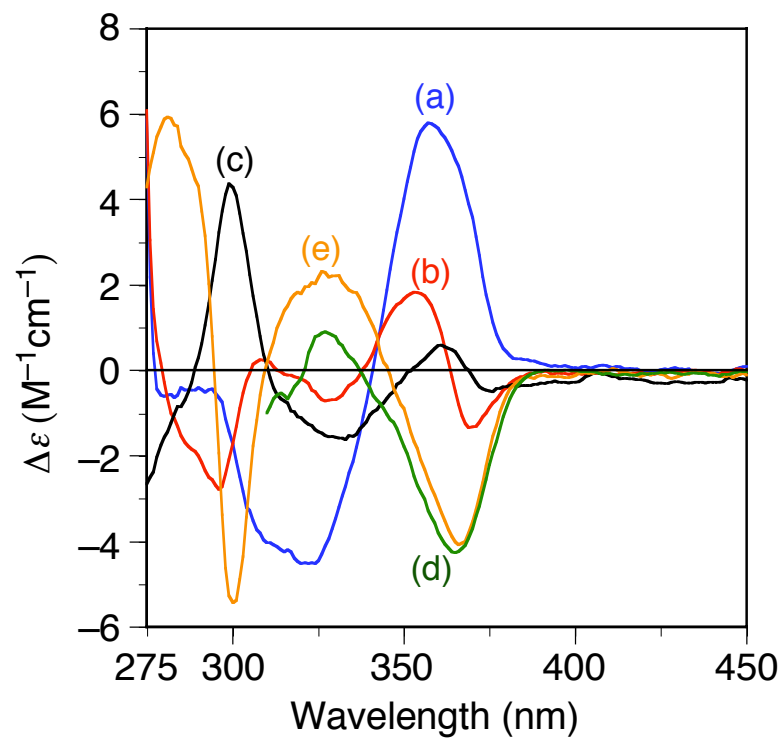

Figure S-2. CD spectra of poly-5c with $(1 R, 2 R)-6$ (a, blue line) and $(1 R, 2 R)-7$ (b, red line) in THF, $(1 R, 2 R)-\mathbf{8}(\mathrm{c}$, black line) in THF/CHCl$(1 / 1, \mathrm{v} / \mathrm{v})$, and $(R)-\mathbf{9}(\mathrm{d}$, green line) and $(R)-\mathbf{1 0}(\mathrm{e}$, orange line) in THF at rt. [amines] $/[$ poly-5c] $=40$ and $[$ poly-5c] $=0.0124 \mathrm{mM}$. 


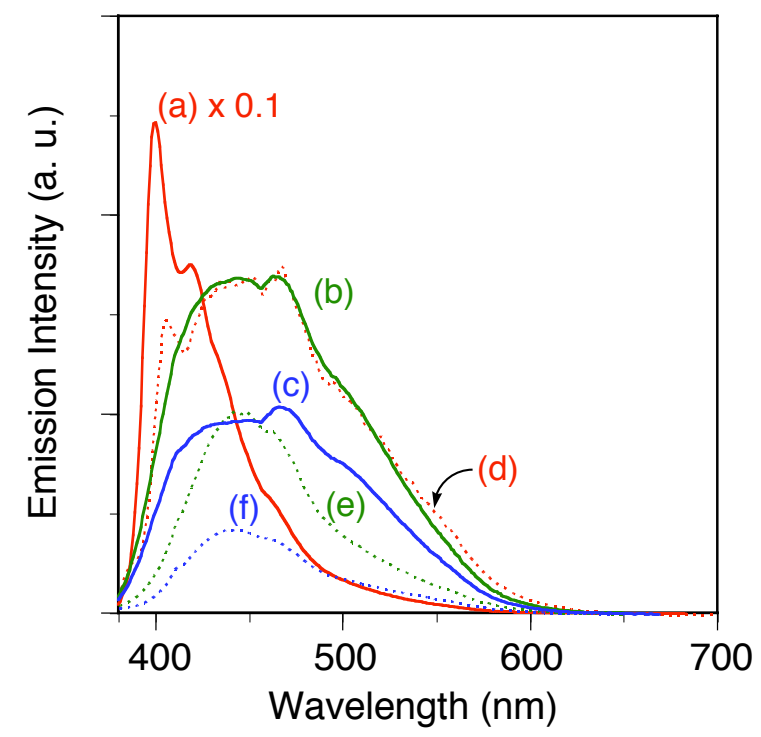

Figure S-3. Fluorescence emission spectra (excitation wavelength $=365 \mathrm{~nm}$ ) of poly-5a $(\mathrm{a}, \mathrm{d})$, poly-5b (b, e), and poly-5c (c, f) with (d, e, f; dotted lines) and without $(1 R, 2 R)-\mathbf{6}(\mathrm{a}, \mathrm{b}, \mathrm{c}$; solid lines) in THF at rt. [6]/[polymer] $=40$ and [polymer $]=0.0124 \mathrm{mM}$. 